\section{The Night Sky in March}

Fuls moon occurs on Mar. 13d. 08h. 26m. U.T., and new moon on Mar. 27d. 07h. 38m. The following conjunctions with the Moon take place: Mar. 5d. 00h., Aldebaran 0.4 S.; Mar. 20d. 1lh., Jupiter $5^{\circ}$ S. ; Mar. 21d. 14h., Saturn $4^{\circ}$ S. ; Mar. 24d. 04h., Mars $4^{\circ}$ S.; Mar. 25d. 12h., Mercury $0.7^{\circ} \mathrm{S} . ;$ Mar. $25 \mathrm{~d} .12 \mathrm{~h}$., Venus $2^{\circ} \mathrm{S}$. In addition to these conjunctions with the Moon. Mercury is in conjunction with Venus on Mar. 25d. 09h., Mercury being $1.9^{\circ} \mathrm{N}$. There will be a total eclipse of the Moon on March 13 and a partial eclipse of the Sun on March 27, both eclipses being invisible at Greenwich. Mercury can be seen during the first few days of the month as an evening star, but conditions rapidly become unfavourable, and after March 5 Mercury will be too close to the Sun for easy observation. There is an occultation of Mercury by the Moon on March 25, visible from Greenwich and lasting from $11 \mathrm{~h}$. $51 \cdot 1 \mathrm{~m}$. to $13 \mathrm{~h} .03 \cdot 6 \mathrm{~m}$. Venus and Mars are too close to the Sun for easy observation. Jupiter is a morning star, rising at $3 \mathrm{~h} .30 \mathrm{~m}$., $2 \mathrm{~h} .40 \mathrm{~m}$. and $1 \mathrm{~h}$. 45m. on March 1, 15 and 31, respectively. It may be seen in the south-east before sunrise; it is in Sagittarius. Its stellar magnitude is $-1 \cdot 7$ and its distance from the Earth in the middle of the month is 490 million miles. Saturn is a morning star, rising at $4 \mathrm{~h} .30 \mathrm{~m} ., 3 \mathrm{~h} .40 \mathrm{~m}$. and $2 \mathrm{~h} .40 \mathrm{~m}$. on March 1,15 and 31 , respectively. It is visible in the south-east before sunrise, and, like Jupiter, is in Sagittarius. Its stellar magnitude is +0.8 and its distance from the Earth on March 15 is 960 million miles. Occultations of stars brighter than magnitude 6 are as follows, observations being made at Greenwich : Mar. 4d. 20h. 40.6m., $\theta^{1}$ Tau. (D); Mar. 4d. 20h. $44 \cdot 2 \mathrm{~m} ., 75$ Tau. $(D)$; Mar. 4d. 21h. $40 \cdot 3 \mathrm{~m} ., 264$ B. Tau. $(D)$; Mar. 5d. 00h. $00 \cdot 2 \mathrm{~m} ., 111$ Tau. $(D)$; Mar. 11d. 3h. 18.0m., o Leo. $(D) ; D$ refers to disappearance. The vernal equinox occurs on March $20 \mathrm{~d}$. 15h.

\section{Announcements}

A DEcision by the U.S.S.R. to join the International Federation of Computer Societies brings the number of nations which have ratified the statutes of this new international organization up to twelve. The Academy of Sciences of the U.S.S.R. will be represented in the Federation by its Computing Centre.

AN international symposium on Growth: Molecule, Cell and Organism will be held at Purdue University, Lafayette, Indiana, during June 16-18. Further information can be obtained from Prof. M. X. Zarrow, Department of Biological Sciences, Purdue University.

The annual International Starch Conference is to be held at the West German Starch Research Station, Detmold, during April 20-22. Further information can be obtained from W. Kempf, Cereal Research Station, P.O. Box 23, Detmold, West Germany.

A CONFERENCE on the Computing Laboratory in the Technical College is to be held during May 27-28 at the Hatfield Technical College, which is sponsoring it. Further details can be obtained from W. A. J. Chapman, Department of Mathematies, Hatfield Technical College, Hertfordshire.

THE Chemical Society is organizing a symposium on Physical, Chemical and Biological Methods of
Study in High Molecular Weight Carbohydrates, to be held in Edinburgh during July 12-14, 1960. Further information can be obtained from the General Secretary, Chemical Society, Burlington House, London, W.I.

The fifth International Congress on Nutrition will be held in Washington, D.C., during September 1-7, under the auspices of the International Union of Nutritional Sciences. Dr. C. Glen King (The Nutrition Foundation, New York City) will preside over the Congress. Further information can be obtained from Dr. Milton O. Lee, 9650 Wisconsin Avenue, Washington 14, D.C.

The general programme of the Madrid Sectional Meeting of the World Power Conference during June 5-9 has now been published. British subjects wishing to obtain further information should write to the Secretary, British National Committee, 201-2 Grand Buildings, Trafalgar Square, London, W.C.2, from whom copies of the programme can also be obtained.

A conference on Solid State Microwave Amplifiers is being organized by the Electronics Group of the Institute of Physics, in conjunction with the Radio Spectroscopy Group, at the University of Nottingham during April 6-8. Further details can be obtained from the Secretary, Institute of Physics, 47 Belgrave Square, London, S.W.1.

ThE International Medical Congress, Ltd, which has a strong affiliation with the National Foundation of New York, is holding its first International Conference on Congenital Malformations in London during July 18-22. Further information can be obteined from the Executive Secretary-Treasurer, First International Medical Conference on Congenital Malformation, 67 New Bond Street, London, W.1.

The Pesticides Group of the Society of Chemical Industry is organizing a symposium on Fungicides in Agriculture and Horticulture in the spring of 1961 . It would be appreciated if workers on these subjects who may wish to submit a contribution to this sym. posium would get in touch with the hon. secretary of the Pesticides Group, Dr. B. J. Heywood, c/o May and Baker, Ltd., Dagenham, Essex, giving a very brief indication of the scope they would wish to cover.

Prof. R. A. MCCANCE and the Department of Experimental Medicine, Cambridge, are arranging a course on the Clinical Aspects of Nutrition, to be given in the Department of Geology, Cambridge, during April 6-9. The course is open to university and hospital medical and scientific staffs and regis. tered medical practitioners. Further information can be obtained from the Secretary, The Medical School, Tennis Court Road, Cambridge.

THE second European symposium on Chemical Reaction Engineering is to be held at the Koninklijk Instituat voor de Tropen, Amsterdam, during April $28-30$. The symposium is being organized under the auspices of the European Federation for Chemical Engineering by the two Dutch member societies. Further information can be obtained from P. J. Hoftyzer, Central Laboratory, Staatsmijnen in Limburg, Geleen (L), Netherlands.

ERRATUM. We regret that in the communication entitled "Shape of the Precipitate in Immunoelectrophoresis", by Dr. Jan Hirschfeld, in Nature of January 16, p. 164, Fig. 4 has been printed upside down. 